\title{
Reactive force-field molecular dynamic models of iron/oxide/carbon nanocomposites designed for magnetic hyperthermia
}

\author{
Avakyan L.A. ${ }^{1}$, Manukyan A.S. ${ }^{2}$, Paramonova E.V. ${ }^{3}$, Bogdan A.S. ${ }^{1}$, Sukharina G.S. ${ }^{1}$, \\ Sharoyan E.G. ${ }^{2}$, Bugaev L.A. ${ }^{1}$ \\ ${ }^{1}$ Southern Federal University, Rostov-on-Don, Russia \\ ${ }^{2}$ Institute for Physical Research, National Academy of Sciences of Armenia, Ashtarak, Armenia \\ ${ }^{3} I M P B$ RAS - Branch of KIAM RAS, Pushchino, Russia
}

\section{laavakyan@sfedu.ru}

The study is devoted to nanoparticles with an iron core and an oxide shell structure, which are enclosed by an additional carbon layer. Such particles are promising for magnetic hyperthermia due to their stability in an AC magnetic field and the tunability of the magnetic properties by varying of the thickness of the oxide shell. To determine the correspondence between the atomic structure of synthesized nanoparticles to expectations, the core-shell structure with an additional carbon coating is modeled on the basis of classical molecular dynamics with a reactive force field that allows chemical bonds to form and break. The results of the molecular dynamics simulation are compared with the pair radial functions obtained from the analysis of the extended fine structure of X-ray absorption spectra near the $\mathrm{Fe} \mathrm{K}$ edge. The resulting model of the cluster $\mathrm{Fe}_{1564} \mathrm{O}_{409}$ demonstrates the stability of its atomic structure (at least for $4 \mathrm{ps)}$ ) at room temperature. The results can be used to study the efficiency for magnetic hyperthermia and the biological effect of the obtained nanocomposites.

Key words: nanoparticles, atomic structure, MHT, ReaxFF, pair radial distribution function, EXAFS spectroscopy.

\section{Молекулярно-динамические модели на основе реактивного силового поля нанокомпозитов железо / оксид / углерод, разрабатываемых для магнитной гипертермии}

Авакян Л.А. ${ }^{1}$, Манукян А.С. ${ }^{2}$, Парамонова Е.В. ${ }^{3}$, Богдан А.С. ${ }^{1}$, Сухарина Г.С. ${ }^{1}$,

\author{
Шароян Э.Г. ${ }^{2}$, Бугаев Л.А. ${ }^{1}$ \\ ${ }^{1}$ Южный федеральный университет, Ростов-на-Дону, Россия \\ ${ }^{2}$ Институт физических исследований, Национальная академия наук Армении, Аштарак, Армения \\ ${ }^{3}$ ИМПБ РАН - филиал ИПМ им. М.В. Келдыша РАН, Пушино, Россия
}

В работе рассматривается наночастицы с ядром железа и оксидной оболочкой, заключенные в углеродную матрицу. Такие частицы представляются перспективными для задач магнитной гипертермии благодаря их стабильности в переменном магнитном поле и возможностью варьировать магнитные свойства, изменяя толщину оксидной оболочки. Для выяснения соответствия атомной структуры синтезированных наночастиц структуре ядро-оболочка с дополнительным углеродным покрытием проводится моделирование на основе классической молекулярной динамики с реактивным силовым полем, позволяющем химическим связям образовываться и разрываться. Результаты молекулярно-динамического моделирования сопоставляются с парными радиальными функциями, полученными из анализа протяженной тонкой структуры рентгеновских спектров поглощения вблизи Fе К-края. Полученная модель кластера $\mathrm{Fe}_{1564} \mathrm{O}_{409}$ демонстрирует стабильность своей атомной структуры (по крайней мере, в течении 4 пс) при комнатной температуре. Результаты могут быть использованы для изучения эффективности для магнитной гипертермии и биологического эффекта полученных наночастиц.

Ключевые слова: наночастищы, атомная структура, МГT, RеaхFF, парная радиальная функиия распределения, спектроскопия EXAFS. 


\section{Introduction}

The currently used methods for cancer treatment, such as chemotherapy or radiotherapy, can cause collateral damages to the normal tissues in human body, which makes important the search of new methods. The developing methods of targeted drug delivery should not provide any damage to normal tissues [1], but the achieved rate of destruction of cancer cells is currently $\sim 10$ times slower than their division rate [2], which dampends such a treatment.

One of the most promising approaches for cancer treatment is magnetic hyperthermia (MHT) [3], which is based on insertion of magnetic nanoparticles (NPs) in the vicinity of tumor or in the blood stream and exposing of thumor location by external AC magnetic field. The field parameters and concentration of nanoparticles should be tuned to provide a toxic dose of heat to cancer tumor from the one side and to prevent damage of healthy tissues from another side. This can not be done so easily since nanoparticles structure can be modified with time, or under the condition in the body, or even under influence of magnetic field. The last, for example, can lead to agglomeration of the nanoparticles, which has multi-domain magnetic structure unpredictably altering the heat efficiency [5].

Considered here iron, iron oxide and core-shell ironiron oxide nanoparticles are promising materials not only for MHT [6, 7], but also for magnetic resonance imaging [8] and for electrochemical catalysis [9]. Nevertheless the high interest to these nanopaerticles, their structural properties and stability are not well known. For example, the recent TEM and XRD study of iron-core oxide-shell nanoparticles [12] claims that core region should be oxidized with time or after heat treatment, resulting in a hollow-core oxide nanoparticle with poor magnetic properties. This is arguable, and the detailed information on the atomic structure of the coreshell iron-oxide nanocomposites is required for understanding of the processes and reactions, their possible heat activity and morphological stability.

The required information on the atomic structure of iron-based nanoparticles with several nanometer size can be provided using molecular-dynamic (MD) simulations [17], which usually performed to simulate the nucleation and growth of nanoparticles $[18,19]$, and to study of the catalytic processes on the iron surfaces $[20,21]$. The structures predicted by MD simulations can be further verified by comparsion of theroretical and experimental radial distribution functions (RDFs). Though the usual practice is to extract RDFs from Xray or neutron scattering experiments, in current study they will extracted from the X-ray absorption spectra at Fe K-edge.

\section{Experimental and theoretical methods}

\subsection{Experimental methods}

The iron (Fe/C) and iron-core oxide-shell $(\mathrm{Fe} / \mathrm{FeOx} / \mathrm{C})$ nanoparticles were synthesized by solid state pyrolysis of iron phthalocyanine [22]. The iron oxide shell is formed by addition of oxygen in the capsule during pyrolysis. Both types of obtained nanoparticles are expected to be sealed in carbon shell, preventing them from further oxidation by air and agglomeration under external magnetic field.

The Fe K-edge X-ray absorption spectra of the samples were measured at the BM23 beamline of the European Synchrotron Radiation Facility (ESRF, Grenoble, France). The consideration of X-ray absorption near-edge structure (XANES) demonstrated the presence of oxidized iron species varied from 16 to 48 at. \%. The Fourier-transform analysis of Fe K-edge extended X-ray absorption fine structure allowed to determine the parameters of near-neighbor coordination spheres of iron atom absorbing X-ray photon: coordination shell radii $R_{j}$, coordination number $N_{j}$ and Debye-Waller parameter $\sigma_{j}^{2}$, characterizing thermal and structural disorder of coordination shell $j$. The knowledge of these three parameters for several coordination shells allows to reconstruct the pair radial distribution function, according [4]:

$$
g(R)=\sum_{j} N_{j} \frac{1}{\sigma_{j} \sqrt{2 \pi}} \exp \left(-\frac{\left(R-R_{j}\right)^{2}}{2 \sigma_{j}^{2}}\right),
$$

where $R$ is a distance from arbitrary chosen central Fe atom to neighbor atom.

\subsection{Computational methods}

The classical molecular-dynamics were performed using reactive force field ReaxFF [10, 11], which allows the chemical bonds to form and broke during the course of simulation. The parameters of the force field trained on and tested for bulk iron, iron oxides, their surfaces and various hydrocarbons were taken from the study [13]. The running of ReaxFF simulations, including energy and forces calculation and charge equilibration were performed using LAMMPS code [14, 15]. The construction of atomic models, their relaxation, molecular-dynamics runs and RDFs calculations were performed using Atomic Simulation Environment (ASE) [16] and in-house Python scripts.

In order to test the correctness of codes and applicability of ReaxFF method to the study of iron and iron oxides in carbon matrix the RDFs for relaxed iron, iron oxides and iron carbide (cementite) bulk structures were calculated and compared with reference data. The results this test presented on Figure 1 shows that the radii of coordination shell are determined up to $0.1 \AA$, but the relaxation introduces additional disorder in the structure, smearing the coordination shells. 


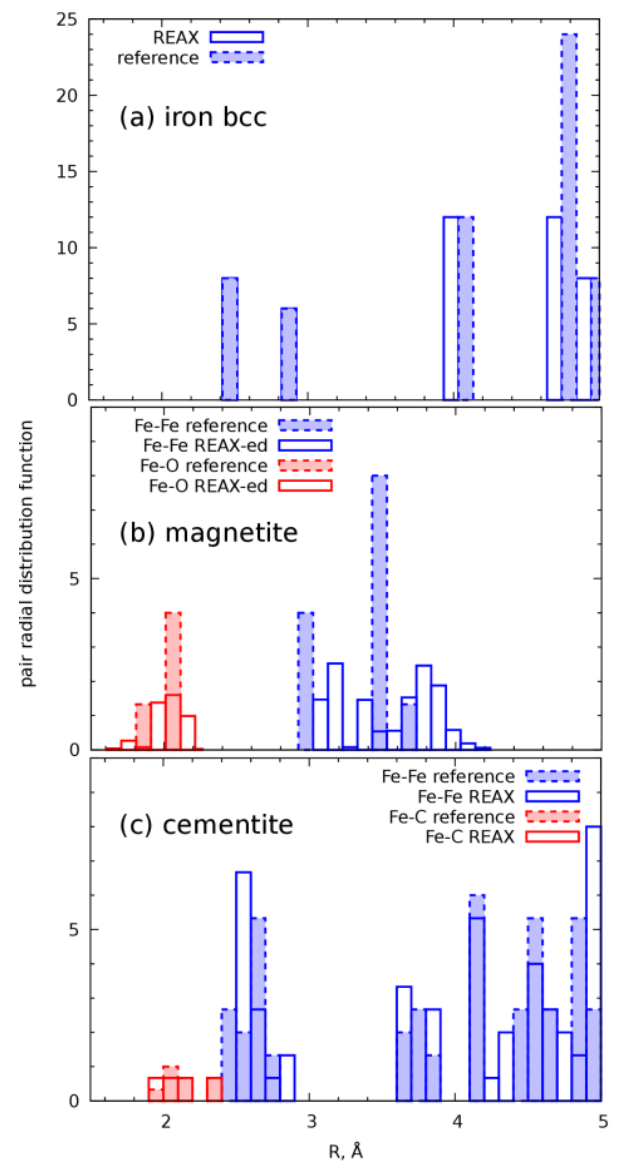

Fig. 1. The comparison of reference (filled dash bars) and calculated (empty bars) for ReaxFF relaxed structures RDFs of (a) iron bcc, (b) magnetite $\mathrm{Fe}_{3} \mathrm{O}_{4}$ and (c) cementite $\mathrm{Fe}_{3} \mathrm{C}$.

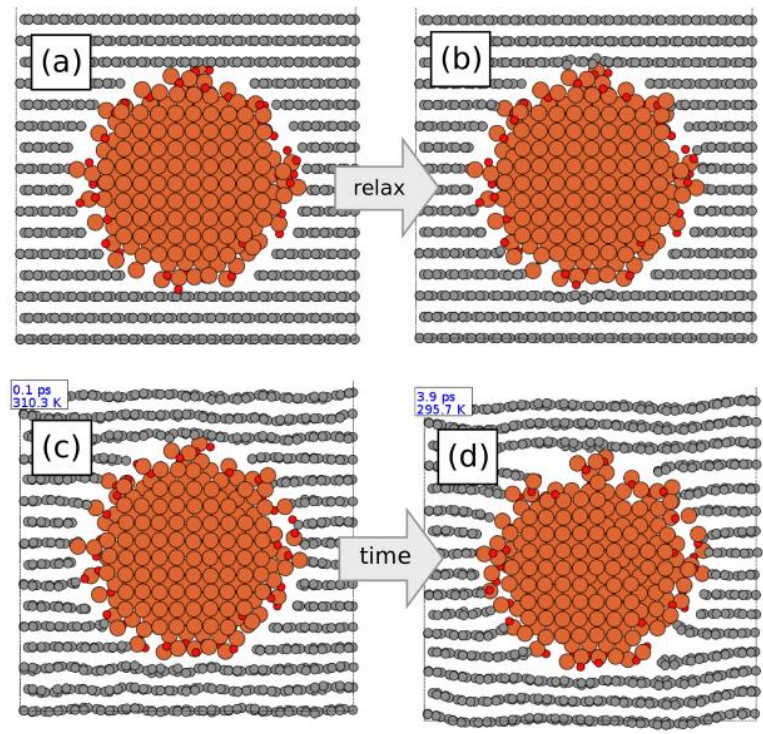

Fig. 2. Slices of atomic structure of $\mathrm{Fe}_{1564} \mathrm{O}_{409}$ embedded in carbon matrix: before (a) and after (b) relaxation; before (c) and after (d) thermolization.

\section{Results and discussion}

Currently the search of atomic models best reproducing experimental RDFs was performed in a "blind" way: different combinations of core and shell radii were supplied to cluster building algorithm, then nanoparticle was relaxed with ReaxFF. In order to consider the effect of the carbon matrix the resulted particle was embedded in the hole made in graphite structure. The relaxation was performed till the total forces become less than $0.1 \mathrm{eV} / \AA \AA$, but no longer than 1000 steps (Fig. 2,a, b). The subsequent thermolization was performed at $300 \mathrm{~K}$ for $4 \mathrm{ps}$ (Fig. 2,c, d) and further 1 ps the data for RDF calculation was gathered.

The best achieved agreement between theoretical and experimental RDF functions is illustrated on Figure 3, where results for the $\mathrm{Fe}_{1564} \mathrm{O}_{409}$ cluster are shown. As can be seen, first three $\mathrm{Fe}-\mathrm{Fe}$ peaks at distances $R=2.5-3.5 \AA$ are well reproduced, but light atoms contributions at distances $R<2.5 \AA$ are underestimated. The positions of far iron coordination shells with $R>3.5 \AA$ are correct, but the corresponding coordination number can suffer from experimental errors.

The relaxed and thermalized structures (Fig. 2,b, d) shows noticeable impact on the structure of surrounding matrix, while carbon contribution on RDF is negligible in comparison with oxygen, and decreases with increasing of particle size.

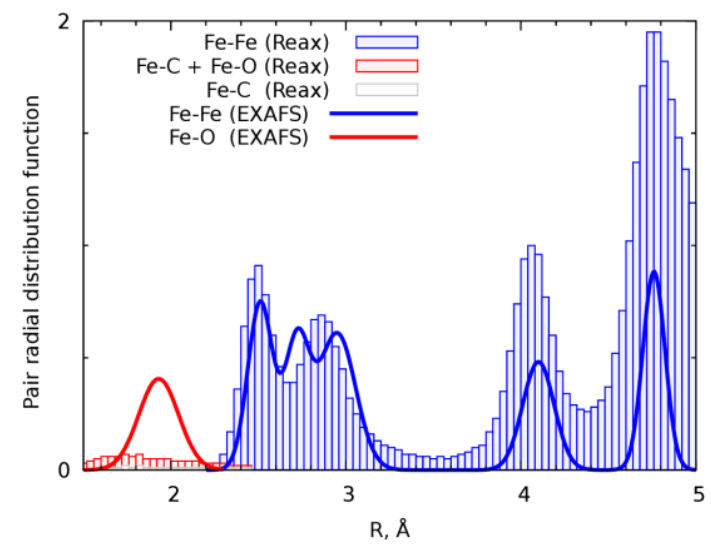

Fig. 3. The comparison of experimental (lines) and theoretical (bars) pair radial distribution functions.

\section{Conculsions}

The performed theoretical and experimental study of iron-contained nanocomposites allows to make the following conclusions:

1) ReaxFF relaxation of bulk iron, iron oxide and iron carbide structures reproduces the structure with $\sim 0.1 \AA$ precision, but introduces additional disorder in the coordination shells.

2) The experimental radial distribution function extracted from X-ray absorbtion spectra at Fe K-edge can be roughtly descriped using $\mathrm{Fe}_{1564} \mathrm{O}_{409}$ cluster model embedded in carbon matrix.

3) Considered structure demonstrates stability at room temperature for at least severl picoseconds, but further stability tests are required. 


\section{Acknowledgments}

The study was supported by RFBR according to the research project № 18-52-05004 Арм_a. The X-ray absorption experiments were performed at ESRF (experiment number MD1068).

\section{References}

1. Bae Y.H., Park K. J. Controlled Release. 2011. V. $153 . \quad$ P. 198-205. doi: 10.1016/j.jconrel.2011.06.001.

2. Roos W.P., Thomas A.D., Kaina B. Nat. Rev. Cancer. 2015. V. 16. P. 20.

3. Piktel E., Niemirowicz K., Wątek M., Wollny T., Deptuła P., Bucki R. Journal of Nanobiotechnology. 2016. V. 14. P. 39. doi: 1 0.1186/s12951-016-0193-x.

4. Borovskii I.B., Vedrinskii R.V., Kraizman V.L., Sachenko V.P. Soviet Physics Uspekhi. 1986. V. 29. P. 539.

5. Dutz S., Hergt R. Nanotechnology. 2014. V. 25. P. 452001. doi: 10.1088/0957-4484/25/45/452001.

6. Obaidat I.M., Issa B., Haik Y. Nanomaterials. 2015. V. 5. P. 63-89. doi: 10.3390/nano5010063.

7. Abenojar E.C., Wickramasinghe S., BasConcepcion J., Samia A.C.S. Progress in Natural Science: Materials International. 2016. V. 26. P. 440-448. doi: 10.1016/j.pnsc.2016.09.004.

8. Blanco-Andujar C., Walter A., Cotin G., Bordeianu C., Mertz D., Felder-Flesch D., BeginColin S. Nanomedicine. 2016. V. 11. P. 1889 1910. doi: $10.2217 / \mathrm{nnm}-2016-5001$.

9. Bock D.C., Pelliccione C.J., Zhang W., Timoshenko J., Knehr K.W., West A.C., Wang F., Li Y., Frenkel A.I., Takeuchi E.S., Takeuchi K.J., Marschilok A.C. Phys. Chem. Chem. Phys. 2017. V. 19. P. 20867-20880. doi: 10.1039/C7CP03312E

10. van Duin A.C.T., Dasgupta S., Lorant F., Goddard W.A. J. Phys. Chem. A. 2001. V. 105. P. 9396-9409. doi: 10.1021/jp004368u.

11. Senftle T.P., Hong S., Islam M.M., Kylasa S.B., Zheng Y., Shin Y.K., Junkermeier C., EngelHerbert R., Janik M.J., Aktulga H.M.,
Verstraelen T., Grama A., van Duin A.C.T. npj Comput. Mater. 2016. V. 2. P. 15011. doi: 10.1038/npjcompumats.2015.11.

12. Nemati Z., Alonso J., Khurshid H., Phan M.H., Srikanth H. RSC Adv. 2016. V. 6. P. 38697-38702. doi: 10.1039/C6RA05064F.

13. Zou C., van Duin A.C.T., Sorescu D.C. Topics in Catalysis. 2012. V. 55. P. 391-401. doi: 10.1007/s11244-012-9796-0.

14. Plimpton S. J. Comput. Phys. 1995. V. 117. P. 119. doi: $10.1006 /$ jeph.1995.1039.

15. Aktulga H.M., Fogarty J.C., Pandit S.A., Grama A.Y. Parallel Computing. 2012. V. 38. P. 245-259.

16. Larsen A.H., Mortensen J.J., Blomqvist J., Castelli I.E., Christensen R., Dułak M., Friis J., Groves M.N., Hammer B., Hargus C., Hermes E.D., Jennings P.C., Jensen P.B., Kermode J., Kitchin J.R., Kolsbjerg E.L., Kubal J., Kaasbjerg K., Lysgaard S., Maronsson J.B., Maxson T., Olsen T., Pastewka L., Peterson A., Rostgaard C., Schiøtz J., Schütt O., Strange M., Thygesen K.S., Vegge T., Vilhelmsen L., Walter M., Zeng Z., Jacobsen K.W. J. Phys.: Condens. Matter. 2017. V. 29. P. 273002.

17. Chui C., Liu W., Xu Y., Zhou Y. SPIN. 2015. V. 5. P. 1540007. doi: 10.1142/S201032471540007X.

18. Zhang H., Waychunas G.A., Banfield J.F. J. Phys. Chem. B. 2015. V. 119. P. 10630-10642. doi: 10.1021/acs.jpcb.5b03801.

19. Shibuta Y., Oguchi K., Takaki T., Ohno M. Scientific Reports. 2015. V. 5. P. 13534.

20. Zou C., Van Duin A. JOM. 2012. V. 64. P. 14261437. doi: 10.1007/s11837-012-0463-5.

21. Liu X., Wen X., Hoffmann R. ACS Catalysis. 2018. V. 8. P. 3365-3375. doi: 10.1021/acscatal.7b04468.

22. Manukyan A., Mirzakhanyan A., Badalyan G., Shirinyan G., Fedorenko A., Lianguzov N., Yuzyuk Y., Bugaev L., Sharoyan E. J. Nanopart. Res. 2012. V. 14. P. 1-7. doi: 10.1007/s11051-0120982-6. 